\title{
PERPAJAKAN DALAM HINDU
}

\author{
Nengah Sukendri \\ STAHN Gde Pudja Mataram \\ sukendri1984@gmail.com
}

Diterima : 7 Maret 2020

Direview : 20 Mei 2020

Diterima : 2 Juni 2020

\begin{abstract}
This Research aims to understand the concept of taxation in according the Hinduism and what is the understanding of hindu people awareness on taxes. A Qualitative approach that used in this research was hermeneutic study, focusing in search of meaning in this matter are particularly on taxation in accord with the Hinduism. The results of the in depth interview by the expertise philosophy, law, tax and practitioners, explained that tax is allowed in the Hinduism. Tax will be picked up by countries through fiskus (tax collector) with the value of the $8 \%$ up to $25 \%$ kind of land and building tax, value added tax , income tax, and stamp duty. The most important thing that tax in Hindu is a yadnya activities, namely sincere devoted activities as the appreciation and devotion residents of the community towards his country. Some holy book as Arthasastra and Manawa Dharmasastra clearly stated that indeed, taxes are allowed in the Hindu.
\end{abstract}

Keyword: Taxation, Veda, Tax Awareness, People of Hindu

\begin{abstract}
Abstrak
Penelitian ini bertujuan untuk mengetahui konsep perpajakan menurut ajaran Hindu dan bagaimana pemahaman dan kesadaran masyarakat Hindu tentang pajak. Pendekatan yang digunakan dalam penelitian ini adalah penelitian kualitatif hermeneutik yang terfokus dalam mencari makna dalam hal ini terutama pada perpajakan menurut ajaran Hindu. Data hasil wawancara secara mendalam oleh ahli filsafat, hukum, dan praktisi pajak, menjelaskan bahwa menurut ajaran agama Hindu pajak dipungut oleh negara melalui fiskus (pemungut pajak) dengan besaran $8 \%$ sampai dengan $25 \%$ berupa PBB, PPn, PPh, dan Bea Meterai. Hal yang penting, pajak dalam ajaran Hindu merupakan
\end{abstract}


sebuah kegiatan yadnya, yaitu kegiatan tulus ikhlas yang ditujukan sebagai bentuk penghormatan dan pengabdian warga masyarakat terhadap negaranya. Beberapa kitab seperti Arthasastra maupun Manawa Dharmasastra secara jelas menyatakan bahwa pajak memang diperkenankan dalam Hindu.

\section{Kata Kunci: Perpajakan, Weda, Kesadaran Pajak, Masyarakat Hindu}

\section{PENDAHULUAN}

Pajak merupakan pungutan yang ditarik oleh pemerintah sebagai salah satu sumber penerimaan untuk pembiayaan pengeluaran yang dilakukan oleh negara. Perbedaan kepentingan antara wajib pajak dengan pemerintah menyebabkan banyak terjadinya permasalahan-permasalahan dalam pemungutan pajak, terlebih lagi sistem perpajakan Indonesia yang dilakukan secara self assesment.

Sistem self assessment merupakan perhitungan jumlah pajak yang dibayarkan oleh wajib pajak yang bersangkutan, yang artinya ada partisipasi aktif wajib pajak dalam menyelenggarakan kegiatan perpajakannya dibutuhkan kepatuhan dan kesadaran oleh wajib pajak (Misman,2016). Jika wajib pajak memiliki kesadaran yang tinggi, maka penerimaan pajak akan optimal dan efeknya pada penerimaan negara juga akan semakin besar. Melalui kesadaran masyarakat dalam memahami arti pentingnya pajak, wajib pajak akan membayar pajaknya secara ikhlas untuk kemajuan negara sehingga mengurangi penghindaran pajak. Kasus penghindaran pajak ternyata cukup besar di Indonesia. Nugeraha et al., . (2016) menyampaikan Realisasi penerimaan pajak Januari-Maret 2016 baru mencapai Rp199,0 triliun atau sekitar 14,6 persen dari target pajak dalam APBN 2016. Jumlah ini malah menunjukkan penurunan Rp4,4 triliun dibanding Januari-Maret 2015 yang mencapai Rp203,4 triliun. Banyaknya potensi pajak yang sulit dijangkau pemerintah membuat target penerimaan pajak menjadi sangat berat. Hal ini 
memerlukan berbagai upaya-upaya nyata, serta diimplementasikan dalam bentuk kebijakan pemerintah untuk menggali penerimaan negara dari sektor perpajakan.

Jotopurnomo dan Mongoting (2013) menyampaikan pembayaran pajak oleh wajib pajak ternyata dipengaruhi oleh kesadaran dan pemahaman masyarakat tentang pajak. Pemahaman tentang perpajakan ternyata telah dikenal sejak lama, bahkan setiap agama ternyata memiliki pandangan tersendiri tentang pajak. Beberapa hal mengenai perpajakan telah tertuang dalam kitab-kitab Hindu dimana pembayaran pajak adalah hal benar, selama pemerintah telah mengayomi masyarakatnya. Hal tersebut tertuang dalam kitab Manawa Dharmasastra X, 118 (Pudja dan Sudartha, 2003) yang menjelaskan:

"Seorang Ksatria yang dalam keadaan susah mengambil seperempat dari hasil panen dinyatakan bebas dari kesalahan, kalau ia melindungi rakyatnya dengan sebaik-baiknya menurut kemampuannya"

Sloka tersebut berhubungan tugas ksatria yang berkecimpung dalam pemerintahan dibenarkan dalam pemungutan pajak, dengan catatan telah benar-benar memperhatikan kesejahteraan rakyatnya sesuai kemampuannya. Hal tersebut dipertegas kembali dalam Arthasastra VI, 6 (Astana dan Anomdiputro, 2003) yang menyatakan:

"Sita (hasil pertanian), Bhaga (bagian hasil untuk negara), Bali (Sumbangan), Kara (pajak), pedagang, penjjaga sungai, kapal penyeberang, kapal-kapal, pelabuhan, padang rumput, jalan-jalan, survei tanah dan penangkapan pencuri, ini membentuk pedesaan."

Melihat isi sloka tersebut maka pajak merupakan salah satu pungutan yang diperkenankan dalam ajaran Hindu. Penting kiranya untuk dilakukan penelitian yang membahas sejauh mana kesadaran pajak bagi Umat Hindu.

Fenomena pajak pada kitab-kitab Hindu memberikan kesempatan penelitian dalam pengembangan konsep khususnya yang terkait dengan konsep 
perpajakan dalam ajaran Agama Hindu. Dhavaleswar et al. (2013) dan Putra (2015) berharap bahwa lebih banyak penelitian yang dapat dibahas dari Kautilya's Arthasastra yang dapat dilakukan untuk penelitian mendatang. Arthasastra telah lama menjadi pedoman bagi umat Hindu di India dan Masyarakat Hindu di Indonesia menggunakan Manawa Dharmasastra dan kitab lainnya seperti Sarasamuscaya sebagai pedoman sejak jaman kerajaan Majapahit. Motivasi dilakukan penelitian ini untuk membangun konsep perpajakan dalam ajaran Hindu. Adapun tujuan dalam penelitian ini adalah untuk mengetahui konsep perpajakan dalam ajaran Agama Hindu dan untuk mengetahui bagaimana pemahaman dan kesadaran masyarakat Hindu tentang Pajak.

\section{TELAAH LITERATUR}

\section{Kajian Pustaka}

Pajak adalah pungutan yang ditarik pemerintah atas wajib pajak tanpa mendapatkan balas jasa langsung. Pajak dapat dibagi dalam 2 golongan yaitu: Pajak Langsung dan Pajak Tidak Langsung. Pajak langsung dari wajib pajak misalnya pajak kekayaan, pajak pendapatan, pajak perseroan. Pajak tidak langsung misalnya pajak penjualan, pajak tontonan dan lain-lain.

Menurut Undang-Undang Nomor 16 Tahun 2009 tentang perubahan keempat atas Undang-Undang nomor 6 Tahun 1983 tentang Ketentuan Umum dan Tata Cara Perpajakan pada Pasal 1 Ayat 1 berbunyi pajak adalah kontribusi wajib kepada Negara yang terutang oleh orang pribadi atau badan yang bersifat memaksa berdasarkan Undang-Undang, dengan tidak mendapatkan imbalan secara langsung dan digunakan untuk keperluan Negara bagi sebesar-besarnya kemakmuran rakyat.

Sedangkan menurut Soemitro dalam buku Mardiasmo (2018), menjelaskan bahwa pajak adalah iuran rakyat kepada kas Negara berdasarkan 
Undang-Undang (yang dapat dipaksakan) dengan tidak mendapat jasa timbal (kontraprestasi) yang langsung dapat ditunjukkan dan yang digunakan untuk membayar pengeluaran umum. Fungsi pajak ada dua yaitu fungsi anggaran dan fungsi mengatur. Syarat pemungutan pajak, agar pemungutan pajak tidak menimbulkan hambatan atau perlawanan harus memenuhi syarat:

1. Pemungutan pajak harus adil (syarat keadilan)

2. Pemungutan pajak harus berdasarkan Undang-Undang (syarat yuridis)

3. Tidak mengganggu perekonomian (syarat ekonomis)

4. Pemungutan pajak harus efisien (syarat financial)

5. Sistem pemungutan pajak harus sederhana Hukum pajak mengatur antara pemerintah (fiscus) selaku pemungut pajak dengan rakyat sebagai wajib pajak. Ada 2 macam hukum pajak, yaitu:

1. Hukum pajak materiil, memuat norma-norma yang menerangkan keadaan perbuatan seperti peristiwa hukum yang dikenai pajak (objek pajak), siapa yang dikenakan pajak (subjek pajak), berapa besar pajak yang dikenakan (tarif pajak), segala sesuatu tentang timbul dan hapusnya utang pajak, dan hubungan hukum antara pemerintah dengan wajib pajak.

2. Hukum pajak formil, memuat bentuk/tata cara untuk mewujudkan hukum materiil menjadi kenyataan (cara melaksanakan hukum pajak materiil).

Tata cara pemungutan pajak, yaitu:

1. Stelsel Pajak

2. Asas Pemungutan Pajak

3. Sistem Pemungutan Pajak

Ada dua ajaran yang mengatur timbulnya utang pajak, yaitu: 
1. Ajaran Formil, utang pajak timbul karena dikeluarkannya surat ketetapan pajak oleh fiskus. Ajaran ini diterapkan pada official assessment system.

2. Ajaran Materiil, utang pajak timbul karena berlakunya Undang-Undang. Seseorang dikenai pajak karena suatu keadaan dan perbuatan. Ajaran ini diterapkan pada self assessment system.

Hapusnya utang pajak dapat disebabkan oleh pembayaran, kompensasi, daluwarsa, pembebasan dan penghapusan. Hambatan terhadap pemungutan pajak dapat terjadi dengan: perlawanan pasif dan perlawanan aktif. Sedangkan, untuk tarif pajak, ada 4 macam yaitu: tarif sebanding/proporsional, tarif tetap, tarif progresif, dan tarif degresif.

Manawa Dharmasastra merupakan salah satu sumber hukum Hindu yang mempunyai kedudukan penting dalam masyarakat Hindu (Pudja dan Sudharta; 1993). Kitab ini dihimpun dengan sistematis oleh Bhagawan Bhrigu, salah seorang penganut ajaran Manu, yaitu pencipta mahakarya ini yang merupakan salah satu Sapta Maha Rsi. Kitab ini disebut dengan Wedangga, yang memuat batang tubuh pada Weda yang tidak dapat dipisahkan dengan Weda Sruti lainnya.

Jenis Wedangga terpenting dalam kitab ini adalah "Kalpa", yang bersumber pada Brahmana Samhita yang ditulis dalam bentuk sutra atau sloka. Menurut Pudja dan Sudharta (1993) Isi dari Wedangga ini memiliki empat topik yaitu:

1. Strauta Sutra (pedoman untuk upacara besar)

2. Grihya Sutra (pedoman untuk berumah tangga)

3. Dharma Sutra (pedoman untuk pemerintahan)

4. Sulwa Sutra (pedoman untuk membuat bangunan/tempat suci)

Kitab-kitab yang terkenal memuat ajaran hukum Hindu yang terdapat di Indonesia adalah Kitab Adi Agama, Rajapratigundala, Sasana-sasana (seperti Siwasasana, Rajasasana, Putrasasana, Rsisasana dan lain 
sebagainya), Kutaramanawa dan Purwadigama. Misalnya kitab Adi Agama adalah salinan dari Kutaramanawa yang menyampaikan berbagai azas Hukum Hindu menurut Bhagawan Bhrigu dan ajaran Manawa Dharmasastra yang telah dipertimbangkan penerapannya menurut kondisi di Indonesia. Sampai dengan saat ini Kitab Manawa Dharmasastra digunakan sebagai acuan utama hukum Hindu di Indonesia.

Sumber lain, Arthasastra merupakan maha karya klasik yang berisi tentang kegiatan manusia dalam bidang politik, tata negara, ekonomi, budaya dan sebagainya yang dapat dipandang sebagai suatu manual atau pegangan bagi seorang pemimpin dalam mengelola negara (Astana dan Anomdiputro; 2003). Arthasastra telah berumur lebih dari 2000 tahun dan sering disebut dalam berbagai kitab -kitab klasik sastra Hindu (seperti Wisnu Purana, Kamandaka-Nitisastra, Panchatantra, dan lain-lain). Namun demikian keberadaan kitab ini baru ditemukan dan diterjemahkan oleh $\mathrm{Dr}$. R. Shamasastry yang menjabat sebagai Director of Archeological Research di Mysore, India. Maha karya tersebut kemudian baru dipublikasikan pada tahun 1905. Sejak itu muncul tanggapan dan respon dari berbagai pihak terhadap kitab Arthasastra, sehingga sampai dengan saat ini Arthasastra telah diterjemahkan dalam berbagai bahasa seperti Jerman, Rusia, Inggris, melayu dan bahkan Indonesia.

Sebenarnya kitab Arthasastra merupakan hasil karya seorang sastrawan yang bernama Kautilya atau Canakya, yang dikenal juga sebagai Visnuguptha. Beliau adalah seorang menteri negara, ahli politik, tokoh agama (Brahmana), dan sastrawan yang hidup kurang lebih sekitar 300 sebelum masehi. Menurut Kautilya, Arthasastra boleh dikatakan suatu kompedium tentang pengelolaan negara secara lengkap dan detail. Di dalamnya juga menggambarkan pandangan Hindu dalam bidang politik, tata negara, intelijen, kepemimpinan, ekonomi, hukum, filsafat, sampai dengan pengobatan dan ilmu magis. 


\section{Penelitian Yang Relevan}

Manajemen adalah bidang interdisipliner dengan kontribusi dari berbagai bidang seperti psikologi, psikologi sosial, Sosiologi, antropologi, ilmu politik, ekonomi dan keuangan. Melalui informasi yang menglobal saat ini, maka dimungkinkan untuk mengembangkan pengetahuan yang mendalam tentang model masa lalu dan sekarang, teori dan proses untuk mengelola secara efektif dan cerdas. Praktek manajemen kontemporer ini meresap dalam setiap aspek kehidupan manusia dalam semua jenis organisasi. Pada Kautilya Arthasastra, ada lima ajaran sutra Kautilya yang relevan dengan dasar-dasar manajemen organisasi (Dhavaleswar et al.; 2013). Pertama, Sukhasya Mulam Dharmah yang artinya dasar dari kebahagiaan adalah kebenaran atau etika. Dharmasya Mulam Arthah merupakan kebenaran atau etika adalah sumber daya. Arthasya Mulam Rajyam adalah dasar dari sumber daya negara atau institusi (organisasi atau perusahaan). Rajyamulam Indriyajayah artinya penyelamat organisasi atau perusahaan berakar pada rasa atau intuisi dan yang terakhir Indriyajayasya Mulam Vinayah adalah dasar organisasi melalui pelatihan dan kedisiplinan.

Dasar-dasar manajemen dalam organisasi yang terungkap dari Arthasastra, yang dapat memberikan petunjuk kepada manajer dan pemimpin organisasi. Kautilya menggunakan pendekatan internal untuk manajemen, yang merupakan manajemen diri terlebih dahulu sebelum pengelolaan semua hal lain. Kautilya menyarankan masa depan organisasi, dilakukan oleh manajer dan pemimpin pertama kali dengan menaklukkan musuh dalam diri manusia seperti hasrat, kemarahan, keserakahan, kesombongan, kegilaan, iri hati, kesombongan atau egoisme, seperti yang sering dikatakan bahwa orang yang menaklukkan diri untuk menaklukkan semua. Analisis Kautilya Arthasastra di bidang manajemen organisasi seperti strategi manajemen, manajemen sumber daya manusia dan manajemen keuangan, merupakan kajian menarik dimasa yang akan datang untuk diteliti (Muniapan; 2008). 
Kautilya secara implisit mengajukan teori tenaga kerja dan juga menyusun undang-undang ekonomi yang terkait dengan kontrak, properti dan gugatan, yang dipromosikan efisiensi ekonomi dan mendorong perilaku beretika (Sihag: 2009). Kautilya menganjurkan teori kontrak antara penguasa dengan masyarakat, yang menunjukkan raja diberi gaji seperti karyawan sebagai bentuk motivasi moral. Contohnya raja yang melakukan tugasnya untuk melindungi umat rakyatnya secara adil dan sesuai hukum untuk mendapatkan surga.

Shyam dan Sunder (2008), menggunakan Kitab Arthasastra yang sudah diterjemahkan dalam Bahasa Inggris. Beberapa bagian dari Arthasastra tersebut menjelaskan tentang ekonomi, perdagangan, kontrol akuntansi, auditing, peraturan dan governance. Dalam bidang akuntansi, Kautilya mengembangkan aturan tentang pembukuan untuk merekam dan mengklasifikasikan data ekonomi, menekankan adanya audit secara berkala, serta pemisahaan peran antara auditor dengan bendahara (Sihag: 2004). Hal ini dilakukan dalam rangka meningkatkan akuntabilitas dan spesialisasi serta mengurangi timbulnya konflik manajemen.

Kaitannya dengan tata kelola menunjukkan bagaimana tulisan Kautilya sebagai sebuah panduan sistem pemerintahan cukup modern konsep dan kontemporer. Saat ini pemikiran dan tulisan-tulisan Kautilya telah menarik perhatian tidak hanya para peneliti akademis tetapi juga banyak sekarang pemikir, pengamat administrasi dan pemimpin politik, yang berisi tentang filsafat, prinsip-prinsip, nasihat dan saran yang terkandung dalam dua Kejadian yang secara nyata terjadi dalam Ramayana dan Mahabharata yang memiliki relevansi besar bahkan saat ini dalam hal prinsip-prinsip dasar ketatanegaraan (Sharma; 2005). Sebagian besar konsep yaitu tata pemerintahan yang baik, respon dari pemerintah, efisiensi administrasi, kesejahteraan dan kemakmuran rakyat, perkembangan masyarakat politik, 
kualitas hidup baik, menjunjung etika dan kemakmuran ekonomi disampaikanleh Kautilya dalam Arthasastranya. Sharma et al. (2009) menyatakan bahwa penerapan corporate governance di India seperti yang tertuang dalam pasal 49 peraturan Securities and Exchange Board of India (SEBI).

Putra (2015) meneliti konsep riba dan pembiayaan dalam Ajaran Hindu. Riba dalam konsep Agama Hindu adalah selama pembiayaan tersebut tidak bertentangandengan ajaran dharma, ketika pembiayaan tersebut ada unsur adharma maka tergolong riba. Selain itu diperkenankan pembiayaan sampai dengan 5\% ketika debitur yang meminjam dana tidak memiliki agunan, dan jika lebih dari 5\% maka pembiayaan tersebut termasuk dalam kategori riba. Konsep pembiayaan pada ajaran Hindu intinya membahas tentang tingkat suku bunga yang diperbolehkan adalah paling tinggi sebesar $2 \%$, namun tatkala debitur tidak memiliki agunan maka diperbolehkan memberikan bunga lebih tinggi dari $2 \%$ sampai dengan batas tertinggi $5 \%$. Semakin besar risiko yang dihadapi perusahaan pembiayaan maka semakin tinggi penerapan tingkat bunga yang diberlakukan.

Konsep yang dibahas dalam penelitian ini adalah Konsep Perpajakan dalam ajaran Hindu. Pisau analisis hermeneutik yang memiliki desain rekonstruksi historis, konstruksi sejarah efektif, rekonsruksi makna, idenstitas estetis, permainan tanda, konstruksi pikiran ketiga, makna partisipatif dan penaksiran objektif (Rohman, 2013). Konstruksi sejarah efektif dipilih untuk membangun konsep dalam penelitian ini Kitab-Kitab Hindu yang merupakan teks historis yang direfleksikan pada masa sekarang sebagai sebuah sintesis.

Dalam penelitian ini menggunakan Teori Interaksionisme Simbolik. Adapun teori Interaksionisme Simbolik seorang memperoleh makna atas sesuatu hal melalui interaksi. Bertautan dengan hal tersebut dapat dikatakan bahwa makna adalah hasil interaksi sosial. Makna tidak melekat pada objek, melainkan dinegosasikan melalui penggunaan bahasa. Bahasa adalah bentuk 
dari simbol. Pada dasarnya interaksi manusia menggunakan simbol-simbol, cara manusia menggunakan simbol mempresentasikan apa yang mereka maksudkan untuk berkomunikasi dengan sesamanya. Tanggapan akan pemahaman dan kesadaran umat Hindu dalam hal perpajakan, disimbolikan melalui perilaku dalam proses dan kegiatan pembayaran pajak. Teori simbolik dipergunakan dalam penelitian ini untuk membedah permasalahan pertama melalui penelaahan dan penafsiran secara mendalam dari kitab-kitab Hindu yang menggunakan bahasa sebagai bentuk simbol, dilakukan konstruksi konsep perpajakan menurut ajaran Hindu. Begitu pula pada tujuan penelitian kedua tentang identifikasi pemahaman dan kesadaran umat Hindu dalam hal perpajakan yang menafsirkan teks dimana dalam teks tersebut biasanya menggunakan makna-makna kiasan.

\section{Kerangka Penelitian}

Berdasarkan uraian latar belakang dan tujuan permasalahan penelitian ini ingin mengkonstruksi perpajakan dalam ajaran Hindu. Berikut ini Gambar 2.1 yang memberikan alur kerangka penelitian.

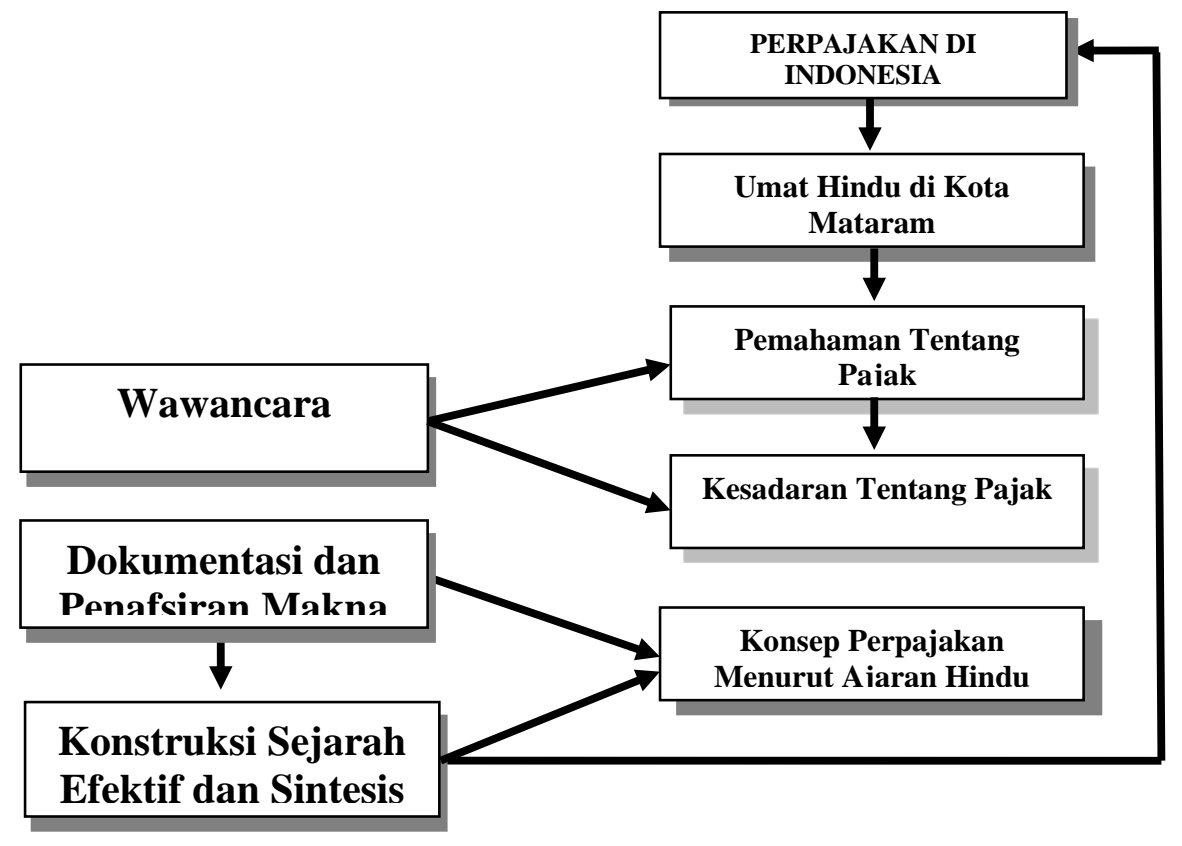

Gambar 2.1, Kerangka Penelitian 
Gambar 2.1 menjelaskan bahwa kondisi saat ini Indonesia telah menerapkan sistem perpajakan berdasarkan UU Nomor 16 tahun 2009 tentang Ketentuan Umum dan Tata Cara Perpajakan. Undang-undang itu mengamanatkan masyarakat untuk mematuhi pembayaran pajak bagi seluruh warga negaranya dan pelaksanaan dari aturan tersebut sangat bergantung kepada pada pemahaman dan kesadaran warga Hindu terhadap ketentuan pajak yang telah ditetapkan. Dalam rangka memperoleh informasi terkait dengan pemahaman dan kesadaran akan pajak tersebut dilakukan wawancara pada warga masyarakat yang beragama Hindu.

Selanjutnya dilakukan metode hermeneutik dalam rangka menafsirkan dari sloka-sloka yang terdapat dalam Kitab Hindu baik Kitab Sruti maupun Kitab Smrti untuk mendapatkan pemahaman dalam upaya mengkonstuksi model perpajakan menurut Hindu. Desain yang digunakan membangun konsep adalah konstruksi sejarah efektif yang hasilnya berupa penggabungan atau sintesis dari isi teks di masa lampau yang dibawa kepada kondisi yang akan datang atau saat ini. Hasil penelitian ini diharapkan kedepannya masyarakat dapat meningkatkan pemahaman dan kesadaran pajak khususnya bagi umat Hindu, karena dengan pemahaman terhadap konsep perpajakan dalam ajaran Hindu akan menambah keyakinan dan juga meningkatkan kesadaran bahwa pembayaran pajak tersebut penting bagi kemakmuran masyarakat.

\section{METODE PENELITIAN}

Pendekatan yang digunakan dalam penelitian ini adalah penelitian kualitatif hermeneutik yang terfokus dalam mencari makna dalam hal ini terutama pada perpajakan menurut ajaran Hindu. Data yang digunakan adalah data primer yaitu hasil wawancara secara mendalam oleh ahli sastra, 
filsafat, hukum, dan praktisi pajak. Teknik penentuan informan menggunakan metode snowball dimana informasi diperoleh dari proses wawancara secara mendalam dan dokumentasi. Teknik analisis dalam penelitian ini dilakukan reduksi data, penyajian data dan penyimpulan dengan analisis teori interaksionisme simbolik.

\section{HASIL PENELITIAN DAN PEMBAHASAN}

\section{Analisis Dependabilitas dan Konfirmabilitas Data}

Penelitian ini menggunakan kode dengan memberikan penomoran terhadap Informan 1 sampai dengan Informan 7, namun penelitian tidak dilakukan secara tim. Jadi, dari keempat prosedur reliabilitas yang ada, digunakan prosedur reliabilitas yang pertama, yaitu pengecekan transkrip. Pengecekan transkrip dalam penelitian ini dilakukan dengan mengevaluasi dan mengecek ulang naskah hasil wawancara dengan rekaman hasil wawancara, sehingga diharapkan dapat meminimalisir tingkat kesalahan yang dilakukan dalam proses pengumpulan data. Setelah itu dilakukan pengkodean pernyataan informan dan cross-check terhadap pernyataan tersebut.

Dalam penelitian kualitatif, dilakukan juga analisis validitas. Analisis ini merupakan pengecekan yang dilakukan dalam penelitian kualitatif dengan tujuan untuk mendapatkan ketepatan dalam menganalisis temuan melalui suatu prosedur penelitian. Strategi pertama merupakan strategi trianggulasi, yang merupakan upaya untuk mencari sumber-sumber dalam menambah informasi, dengan tujuan menguji bukti yang didapat dilapangan. Hasil evaluasi atau uji ini diharapkan dapat menghasilkan justifikasi dari tema yang diteliti.

Penelitian ini menggunakan trianggulasi. Wawancara dilakukan beberapa informan yang berkompeten di bidangnya. Trianggulasi hasil 
wawancara dilakukan dengan cara mengamati data-data sekunder yang diperoleh dari sloka (ayat-ayat) pada Kitab Smrti. Jadi untuk melakukan trianggulasi, dilakukan wawancara dengan ahli filsafat Hindu, ahli sastra Hindu serta ahli hukum dan budaya Hindu, sehingga data hasil wawancara tersebut dapat dianggap valid.

Menurut Yin (2009), ada empat pengujian yang biasa dilakukan untuk menjaga kualitas penelitian ilmu sosial, yaitu validitas konstruk (confirmability), validitas internal (credibility), validitas eksternal (transfermability) dan reliabilitas (dependability). Confirmability diaplikasikan untuk mengidentifikasi dan memastikan bahwa pengukuran operasional sudah benar digunakan sebagai konsep penelitian, yang biasanya dilaksanakan dengan penggunaan data yang lebih dari satu sumber, membangun serangkaian bukti dan membuat konsep laporan. Penggunaan confirmability pada penelitian ini adalah dengan melakukan trianggulasi (penggunaan multi sumber data) dengan sumber data yaitu wawancara ahli filsafat Hindu, ahli sastra Hindu, ahli hukum dan budaya Hindu.

Uji kedua adalah melakukan credibility, yang biasanya digunakan oleh penelitian eksplanatori (penjelasan) atau penelitian tentang hubungan kausal. Uji ini bertujuan agar dapat membangun hubungan kausal yang sesuai dengan kondisi yang ada serta mencegah adanya hubungan yang semu antar variabel. Ada empat taktik yang dapat digunakan antara lain pencocokan jalur, membangun penjelasan, menyampaikan penjelasan yang berlawanan, dan penggunaan model yang logis. Keempat taktik tersebut diterapkan pada tahap analisis data (hasil pengujian). Bahkan pada strategi penjodohan pola yang menggunakan studi kepustakaan terhadap kitab-kitab Smrti Hindu seperti Kitab Manawa Dharmasastra dan Artha Sastra dapat digunakan untuk menguatkan validitas, sehingga secara otomatis pola antar variabel yang diuji telah memenuhi syarat. 
Pengujian transfermability juga dilakukan, yang membantu dalam mendefinisikan pada bidang yang mana temuan-temuan dalam penelitian dapat digeneralisasi. Taktik yang dapat digunakan adalah penggunaan teori dan penelitian terdahulu, terutama penelitian serupa yang telah dilakukan di India seperti yang dilakukan oleh Dhavaleswar et al. (2013). Suatu teori harus diuji melalui replikasi pada lingkungan kedua dan ketiga, dan teori tersebut telah menspesifikasikan bahwa hasil yang sama harus terjadi (Yin, 2009). Sekali replikasi tersebut dilakukan, hasilnya akan diterima di banyak lingkungan serupa, meskipun replikasi tersebut lebih lanjut belum dilakukan.

Pengujian dependenbility menggambarkan operasionalisasi kegiatan penelitian yang merupakan prosedur pengumpulan data. Taktik yang dapat digunakan dalam pengujian reliabilitas ini dengan penggunaan protokol penelitian dan mengembangkan database hasil wawancara penelitian, yang keduanya dapat dilakukan pada tahap pengumpulan data. Penelitian ini menggunakan protokol penelitian berupa petunjuk pertanyaan atau guidance question, yang sering disebut juga dengan daftar pertanyaan.

\section{Analisis Data}

Setelah dilakukan penghimpunan literatur dan kepustakaan terhadap kitab-kitab Smrti yang dilanjutkan dengan wawancara bantuan protokol penelitian, selanjutnya dilakukan wawancara kepada pihak-pihak yang berkompeten diantaranya ahli filsafat Hindu, ahli sastra Hindu dan ahli Hukum dan Budaya Hindu dalam rangka menguji kesahihan data, reduksi dan pembentukantema pada tahap analisis data yang telah terkumpul. Data tersebut dilihat konsistensinya dengan mencocokkan jalur, membangun penjelasan, menyampaikan penjelasan yang berlawanan (rival) dan penggunaan model yang logis. Hal ini merupakan bentuk pengujian validitas eksternal. 
Pada tahap analisis data digunakan Tabel manipulasi yang menggunakan teknik analisis dan tabulasi data. Tabulasi data ini berupa Tabel manipulasi yang mengadopsi teknik dari Miles dan Huberman, dalam Yin (2009). Menurut Miles Huberman (2009) dalam melaksanakan analisis data tersebut, ada tiga macam kegiatan dalam analisis data kualitatif, yaitu, reduksi data, data display dalam bentuk tabel, dan penarikan atau verikasi kesimpulan.

\section{Reduksi Data}

Reduksi data merujuk pada proses pemilihan, pemokusan, penyederhanaan, abstraksi, dan pentransformasian data mentah yang terjadi dalam catatan lapangan tertulis.

\section{Konsep Perpajakan dalam Hindu:}

Pada penelitian ini disampaikan beberapa petikan ayat (sloka) dari beberapa kitab yang relevan dengan tujuan penelitian. Melalui penelitian ini dapat dikutip beberapa sloka Arthasastra Buku II VI, 3 (Astana dan Anomdiputro, 2003) yang menyatakan:

"Sita (hasil pertanian), Bhaga (bagian hasil untuk negara), Bali (Sumbangan), Kara (pajak), pedagang, penjaga sungai, kapal penyeberang, kapal-kapal, pelabuhan, padang rumput, jalan-jalan, survei tanah dan penangkapan pencuri, ini membentuk pedesaan."

Artinya: sumber-sumber perekonomian termasuk didalamnya terdapat pajak merupakan yang menyebabkan sebuah desa terbentuk, karena ada sumber pendapatan maka masyarakat cenderung berkumpul untuk melakukan pertukaran.

Astana dan Anomdiputro (2003) mempertegas pentingnya pajak dalam Arthasastra Buku II VI, 10 yaitu:

"Mula (modal), Bhaga (penyertaan), Vyaji (biaya tambahan), Parigha (pajak monopoli), Klrpta (pajak yang ditentukan), Rupikam (beban 
pabrik) dan denda, inilah yang membentuk Ayamukha (pokok-pokok pendapatan)"

Artinya: Pajak merupakan bagian pendapatan yang sangat penting yang merupakan sumber atau nantinya digunakan untuk membiayai pengeluaranpengeluaran pemerintah.

Kegiatan memungut pajak kepada masyarakat memang diperkenankan dalam ajaran Hindu yang dipertegas dalam Manawa Dharmasastra X, 119 (Pudja dan Sudartha, 2003) berikut:

"Kewajiban yang Aneh adalah penaklukan ia harus tidak kembali dalam hidupnya, setelah melindungi waisyadengan senjatanya, Ia boleh memungut Pajak yang sah".

Artinya: Secara umum hal yang lumrah bagi seorang raja atau ksatria yang jika dianalogikan dalam kondisi sekarang adalah pemerintah memungut pajak pada rakyatnya, selama pemerintah tidak melupakan kewajiban untuk melindungi dan mengayomi rakyatnya, karena pada dasarnya pembayaran pajak tersebut akan dikembalikan pada masyarakat dalam bentuk fasilitas.

Mengingat sangat pentingnya Pajak bagi Pemerintah dalam pemberian fasilitas rakyatnya, maka perlu kiranya ditentukan obyek-obyek pajak yang dijelaskan Arthasastra Buku II XXXV, 3 :

"Ia harus mencatat jumlah desa dengan menentukan batasannya, jumlah ladang dengan menghitung (ladang) yang dibajak dan yang tidak, ladang kering dan basah, taman, kebun sayur (bunga dan buah) yang dipagari, hutan, bangunan, cagar alam, puri, irigasi, tempat kremasi, rumah istirahat, tempat untuk minum air, tempat suci, ladang rumput dan jalan, dan tentang hadiah, penjualan, pemberian dan pembebasan mengenai batas desa dan ladang, dan (mencatat) rumah dari jumlah pembayar pajak dan bukan pembayar pajak."

Berkaitan dengan kutipan sloka-sloka tersebut, kegiatan dan beberapa obyek yang dapat dikenakan pajak memang dalam ajaran Hindu diperbolehkan untuk memunggutnya sebagai sumber pendapatan. Dalam sloka Artha sastra 
tersebut nampak adanya Pajak Bumi dan Bangunan (PBB) dikenakan pada Masyarakat, sehingga perlu adanya kejelasan batas pekarangan dan ladang. Jenis pajak lainnya juga dikenakan pada masyrakat juga tertuang secara jelas pada sloka berikut ini:

"Dan Tentang Kegiatan mengenai Barang yang Bernilai Tinggi dan Rendah yang dihasilkan di luar negeri (dan) diimpor melalui jalan air atau jalan darat, mereka harus cari tahu jumlah pajak, tol jalan, biaya pengawalan, Biaya pada stasiun Polisi dan Feri, Bagian , Makanan dan Hadiah."

(Arthasastra. Buku II XXXV. 12)

Artinya: Berdasarkan sloka tersebut nampak bahwa dalam ajaran Hindu telah mengenal pajak atau bea masuk barang masuk (impor), sehingga kegiatan bea cukai sudah berlaku sudah sejak lama.

Selain itu dijelaskan tentang pajak penggunaan jalan (TOL) dan hal tersebut diperjelas kembali pada Arthasastra, Buku II XXII.2 tentang Barang Keluar dan Barang yang Masuk dikenakan pajak.

Setelah adanya pemaparan tentang jenis pajak yang dikenakan, secara jelas Arthasastra, Buku II XXII.6 mengungkapkan adanya tarif pajak yaitu:

"Tentang Ksauma, dukula, benang sutera, baju perang, orapinament kuning, arsenik mereh, antimoni, vermilyun, logam berbagai jenis dan barang tambang, tentang kayu cendana, aloe, bumbu, fermentasi, barang kecil, tentang gading, cover tempat tidur, penutup dan kain sutera dan tentang barang dari kambing dan kambing jantan (pajak dikenakan) sepersepuluh atau seperlima belas bagian".

Selain itu dijelaskan tarif pajak dari pakaian, hasil bumi dan peternakan sebagai berikut:

"Tentang pakaian, binatang berkaki empat dan berkaki dua, benang, katun, parfum, obat, kayu bambu, kulit kayu, barang dari kulit dan dari tanah, dan tentang gandum, lemak, gula, garam, anggur, makanan yang sudah dimasak dan sebagainya, (pajak) adalah seperdua puluh atau seperdua puluh lima bagian."

(Arthasastra, Buku II XXII.7)

Artinya :Kedua sloka yaitu Arthasastra, Buku II XXII.6 danArthasastra, Buku

II XXII.7menunjukan bahwa ajaran Kautilya memperbolehkan pemungutan 
pajak dari hasil penjualan atau PPn yang besaranya berkisar antara $20 \%$ sampai dengan $25 \%$, bergantung dari jenis barang yang diperjualbelikan. Dalam Manawa Dharmasastra X, 120 (Pudja dan Sudartha, 2003)

"Dari Waisya seperdelapan bagian sebagai pajak kacang-kacangan, seperduapuluh bagian atas keuntungan atas keuntungan penjualan yang jumlahnya setidak-tidaknya sebanyak satu karsapana, Sudra, Seniman dan ahli mesin akan menguntungkan raja dengan bekerja padanya."

Artinya : untuk penjualan hasil bumi seperti kacang-kacangan, petani dikenakan tarif PPn atau pajak penjualan sebesar 8\%, dan untuk hasil keuntungan atau laba dari usaha secara keseluruhan maka pengusaha dikenakan pajak penghasilan atau PPH sebesar $20 \%$.

Selain besaran dan tarif Pajak yang ditentukan Arthasastra juga membahas siapa yang berhak memungut pajak.

"Pengumpul Bea Cukai dan Tol harus mendirikan rumah bea cukai dan bendera yang menghadap ketimur dan ke Utara dekat pintu gerbang besar (kota)."

(Arthasastra,Buku II XXI, 1)

Diperjelas kembali dalam Sloka berikutnya bahwa:

Penerima Pajak sejumlah empat atau lima orang, harus mencatat perincian tentang para pedagang yang datang dengan karavan, siapa mereka, dari mana, berapa banyak barang dagangan, dan dimana pas identitas dikeluarkan dan pembuatan stempel dibuat.

(Arthasastra,Buku II XXI, 2)

Artinya: Untuk satu obyek pajak, setidaknya ada 4 sampai dengan 5 orang yang melakukan pemeriksaan agar penilaian terhadap obyek pajak tersebut valid dan tepat pembayarannya berdasarkan jenis dan jumlahnya oleh fiskus (pemungut pajak). 


\section{Pemahaman dan Kesadaran Pajak umat hindu:}

Umat Hindu secara umum telah memiliki pemahaman tentang pajak yaitu diperjelas dari hasil penyampaian informan.

\section{Penyajian Data}

Setelah dilakukan reduksi hasil wawancara, selanjutnya dilakukan display atau penyajian model data yang merupakan kumpulan informasi sebagai dasar pendeskripsian kesimpulan dan pengambilan tindakan. Model data yang sering digunakan dalam metode kualitatif adalah narasi.

Tabel berikut merupakan gambaran pendisplaian data beserta tema atau topik yang terbentuk yang merupakan hasil reduksi data dari sloka-sloka yang ada pada Kitab Smrti dan hasil wawancara para informan.

\section{Tabel 4.1 Pendisplaian Data}

\begin{tabular}{|c|c|c|c|}
\hline No. & $\begin{array}{c}\text { Tujuan } \\
\text { Penelitian }\end{array}$ & Tema & Sumber \\
\hline 1. & $\begin{array}{l}\text { Konsep } \\
\text { Pajak } \\
\text { Dalam Kitab } \\
\text { Hindu }\end{array}$ & $\begin{array}{l}\text { - Tarif Pajak Bervariasi antara } 8 \% \\
\text { s/d } 25 \% \\
\text { - Adanya Fiskus }\end{array}$ & $\begin{array}{l}\text { - AS II,VI,3; AS } \\
\text { II,VI,10 } \\
\text { - MD X,119 } \\
\text { AS II,XXXV,3; AS } \\
\text { II, XXXX,12; AS,II, } \\
\text { XXXV, 12; II XXII.2 } \\
\text { - AS II,XXII.6; AS } \\
\text { II,XXII.7; MD,X, } \\
\text { 120 } \\
\text { - AS, II XXI, 1; AS, } \\
\text { II XXI, } 2\end{array}$ \\
\hline 2. & $\begin{array}{l}\text { Pemahaman } \\
\text { Masyarakat } \\
\text { Hindu } \\
\text { Tentang } \\
\text { Pajak }\end{array}$ & $\begin{array}{l}\text { - Pajak Kewajiban yang memaksa } \\
\text { - Sadar dan sudah bayar } \\
\text { - Hindu Boleh Dan Wajib Bayar Pajak } \\
\text { - Sumber Kitab Sruti \& Smerti } \\
\text { - Kesadaran Umat Hindu akan Pajak } \\
\text { - Objek Pajak yang sudah dibayar } \\
\text { - Umat } \\
\text { - Pengetahuan Jenis Pajak } \\
\text { - Sangsi bagi tidak membayar Pajak }\end{array}$ & $\begin{array}{l}\cdot i 2, i 3, i 4, i 5, i 6, i 7 \\
\cdot i 2, i 3, i 4, i 5, i 6, i 7 \\
\cdot i 1, i 2, i 3, i 4, i 5, i 6, i 7 \\
\cdot i 1, i 2, i 3 i 4, i 6 \text { i7 } \\
\cdot i 1, i 2, i 3, i 4, i 7 \\
\cdot i 1, i 3, i 4, \mathrm{i} 5, \mathrm{i} 7 \\
\cdot i 1, i 3, i 4, i 5, i 7 \\
\cdot i 1, i 2, i 3, i 5, i 6, i 7\end{array}$ \\
\hline
\end{tabular}




- Solusi Bagi Penundaan/tidak
membayar pajak dengan
pendekatan sosialisasi

Ket: MD : Manawa Dharmasastra

AS: Arthasastra

\begin{tabular}{llll} 
i1 & : Informan 1 & i5 & \multicolumn{2}{c}{ : Informan 5 } \\
i2 & : Informan 2 & i6 & : Informan 6 \\
i3 & $:$ Informan 3 & i7 & : Informan 7 \\
i4 & : Informan 4 & &
\end{tabular}

Berdasarkan hasil pendisplaian data pada tabel 4.1, didapatkan sembilan tema utama dalam penelitiaan ini. Kesembilan tema tersebut dicocokkan atau diuji kevaliditasannya melalui berbagai sumber informasi yang digunakan seperti Manawa Dharmasastra, Arthasastra, Informan 1, Informan 2, Informan 3, Informan 4, Informan 5, Informan 6 dan Informan 7. Setelah melihat tingkat kesesuaian antar berbagai sumber informasi tersebut, tema-tema pada tujuan pertama (Konsep Pajak Dalam Kitab Hindu) itu mengerucut menjadi empat tema besar dan pada tujuan penelitian kedua (Pemahaman Masyarakat Hindu Tentang Pajak) terbentuk Sembilan tema.

Empat tema dalam menjawab tujuan penelitian konsep pajak dalam kitab Hindu adalah Pajak diakui sebagai pendapatan negara, Obyek Pajak dalam kitab dijelaskan berupa PBB, PPn, PPh, Bea Masuk, Tarif Pajak 8\% s.d 25\% dan dijelaskan adanya Fiskus. Sembilan tema utama dalam menjawab tujuan penelitian Pemahaman Masyarakat Hindu Tentang Pajak adalah Pajak adalah kewajiban yang memaksa, Wajib Pajak sadar dan sudah membayar, Hindu memperbolehkan membayar pajak, sumber konsep pajak dari Sruti dan Smerti, Umat Hindu Sadar akan Pajak, Obyek Pajak yang sudah dibayar oleh umat. Pengetahuan Umat tentang Pajak, Ada sangsi bagi yang menunda atau tidak membayar pajak dan solusi bagi wajib pajak yang tidak membayar pajak terutang perlu pendekatan dengan sosialisasi. 
Sukendri: Perpajakan dalam Hindu

\section{Penyimpulan Data}

Penarikan kesimpulan dan verifikasi dilakukan secara singkat berdasarkan pemikiran kembali yang terlintas dalam pikiran orang yang melakukan penelitian. Hal ini juga merupakan suatu tinjauan ulang terhadap catatan dan ringkasan yang ada, melalui peninjauan oleh teman sejawat untuk mengembangkan "kesepakatan intersubjektif", atau juga upaya untuk menempatkan salinan suatu temuan dalam seperangkat data yang lain. Singkatnya, makna-makna yang muncul dari data harus diuji kebenarannya, kekokohannya dan kecocokannya, yang merupakan suatu kegiatan validitas terhadap data yang diambil dan dipergunakan. Jika tidak demikian, data yang kita gunakan dalam proses pengambilan keputusan atau tindakan tidak jelas kebenaran dan kegunaannya.

Oleh karena itu, untuk pemeriksaan atau verifikasi kesimpulan yang ditarik, maka digunakan hasil wawancara dengan 3 Informan agar kesimpulan yang diambil dapat dipertanggungjawabkan dan tidak diragukan keabsahannya. Berikut ini hasil penarikan kesimpulan dan verifikasi yang dilakukan dalam analisis konsep perpajakan. Pembahasan mengenai perpajakan telah secara gambang diakui menjadi pendapatan bagi negara. Hal disebutkan dalam Astana dan Anomdiputro (2003) menyampaikan pentingnya pajak dalam membentuk pendapatan yaitu Arthasastra Buku II VI, 10 :

"Mula (modal), Bhaga (penyertaan), Vyaji (biaya tambahan), Parigha (pajak monopoli), KIrpta (pajak yang ditentukan), Rupikam (beban pabrik) dan denda, inilah yang membentuk Ayamukha (pokok-pokok pendapatan)"

Selain itu kegiatan memungut pajak kepada masyarakat memang diperkenankan dalam ajaran Hindu yang dipertegas dalam Manawa Dharmasastra X, 119 (Pudja dan Sudartha, 2003)

"Kewajiban yang Aneh adalah penaklukan ia harus tidak kembali dalam hidupnya, setelah melindungi waisyadengan senjatanya, Ia boleh memungut Pajak yang sah". 
Melalui beberapa tema yang terbentuk, maka dapat diverifikasi bahwa dalam ajaran agama Hindu, Pajak Dipungut oleh negara melalui fiskus (pemungut pajak) dengan besaran $8 \%$ sampai dengan $25 \%$ berupa PBB, PPn, PPh, dan Bea Meterai.

Verifikasi terhadap beberapa tema yang membentuk kesadaran dan pengetahuan umat Hindu dalam membayar pajak sudah tergolong baik, sehinga perlu dipertahankan atau bahkan ditingkatkan sehingga kesadaran meningkat melalui sosialisasi dan sangsi bagi mereka yang masih menunda atau tidak membayar pajak. Masyarakat Hindu sudah memahami pajak sebagai kewajiaban warga negara namun tetap perlu sosialisasi dan sangsi pajak agar tetap mempertahankan kelancaran membayar pajak.

\section{Pembahasan}

Pada tahap verifikasi terhadap tema-tema yang muncul dalam pendisplaian data, didapatkan dua buah proposisi. Proposisi pertama mengungkapkan bahwa Perpajakan dalam Hindu adanya pengakuan pajak sebagai salah satu sumber pendapatan yang dapat dipungut oleh negara melalui para fiskusnya dengan pembayaran berkisar $8 \%$ sampai dengan $25 \%$. Sedangkan, Implementasi pengenaan tarif pajak dan sangsi pajak di Indonesia saat ini sudah diatur sesuai dengan Ketentuan Umum dan Tata Cara Perpajakan Undang-Undang Nomor 28 Tahun 2007 dan Undang Undang Nomor 16 Tahun 2009. Misal: untuk pajak penghasilan, pengenaan tarif PPh minimal $5 \%$ sampai dengan $30 \%$ (sudah diatur dalam Undang-Undang yang disesuaikan dengan jumlah penghasilan yang diterima). Sedangkan sangsi administrasi berupa denda bervariasi antara Rp 100.000,- untuk SPT masa sampai dengan Rp 1.000.000,- untuk SPT tahunan PPh wajib pajak orang pribadi (sesuai dengan ketentuan yang berlaku). 
Pada dasarnya semua agama pasti mengatur baik kehidupan bereligi maupun berbangsa dan bernegara. Tetapi tidak semua umat manusia yang memahami hal-hal semacam itu, kecenderungan umat manusia yang beragama ini lebih banyak mempelajari atau mendalami tentang religius Ketuhanan. Bagaimana pandangan agama terhadap kehidupan umat manusia yang hidup. Kebanyakan orang berbicara tentang agama itu yang akan datang bukan yang sekarang. Kematian besok bagaimana dan bekal untuk mati bagaimana. Tetapi jarang orang yang mau mempelajari bagaimana hidup. Di Hindu, sudah diajarkan sistematis di Hindu bahwa ada kitab-kitab suci hindu mengajarkan tentang bagaimana orang hidup dan bagaimana orang yang akan meninggalkan dunia atau dunia niskala.

Salah satu contoh dalam kehidupan beragama, Hindu mengajarkan Catur Weda, Reg Weda bagaimana memuja Tuhan dalam manifestasinya dalam perwujudan-perwujudan sinarnya disebut para dewa, Yajur Weda berbicara tentang bagaimana sebuah ritualitas, sama weda berbicara tentang bagaimana mengiramakan, melantunkan syair-syair kidung-kidung suci untuk mengagungkan Tuhan, atharwa weda berbicara tentang hidup dan bagaimana menjalani kehidupan. Begitu juga dengan pajak. Pajak dalam Hindu sudah diatur tetapi tidak semua masyarakat hindu yang pernah membacanya. Pajak adalah sebuah kewajiban bagi umat hindu memberikan apa yang ada pada dirinya dalam bentuk benda atau tenaga kepada penguasa, jaman dulu raja, untuk umat hindu kepada pendetanya memberikan bisa dalam cerita-cerita purana bentuknya seperti dana punia, atau persembahan suci. Pajak adalah persembahan baik persembahan ke atas dengan cara memuja sebuah ritualitas kepada pendeta salah satu wujudnya memberikan kepada orangorang suci sebagai perwakilan Tuhan. Begitu pula dengan persembahan kepada penguasa termasuk kepada sesama, salah satu bentuk secara sederhananya pajak dilihat dalam pandangan hindu. Melalui penelaahan dan penafsiran secara mendalam dari kitab Hindu yang menggunakan bahasa 
sebagai bentuk simbol sehingga dapat memberikan informasi, makna dan dapat mengkomunikasikan kepada masyarakat bagaimana konsep perpajakan menurut ajaran Hindu tersebut, sehingga relevan dengan teori interaksionisme simbolik.

Proposisi kedua menyatakan bahwa kesadaran dan pengetahuan masyarakat Hindu sudah berjalan dengan baik dan agar terus sesuai dengan yang diharapkan maka perlu sosialisasi dan pemberian sangsi secara kontinyu sehingga kondisi tersebut bisa dipertahankan bahkan ditingkatkan. Caranya di Lembaga Hindu bagaimana Parisadha atau Paruman Sulinggih bisa memberikan sebuah edukasi kepada masyarakat betapa pentingnya pajak bagi kelangsungan hidup manusia. Setiap dharma wacana diberikan informasi tentang pajak, tidak hanya berbicara tentang banten, upacara, tetapi juga mengingatkan kewajiban kita sebagai warga negara. Juru penerangnya, Departemen Agama memberikan pemahaman dalam bentuk dharma wacana, dharma tula. Demikian juga di pemerintahan perlu dilakukan penyuluhan. Solusinya dirjen pajak melakukan penyuluhan, serta lembaga hindu sosialisasi ke banjar-banjar pentingnya membayar pajak bagi masyarakat. Sesuai dengan teori interaksionisme simbolik, seseorang memperoleh pemahaman dan kesadaran untuk membayar pajak perlu adanya suatu interaksi dengan pendekatan-pendekatan seperti diadakannya penyuluhan dan sosialisasi baik oleh pemerintah atau pegawai pajak maupun oleh para pendharma wacana, penyuluh atau lembaga Hindu lainnya.

\section{SIMPULAN}

Simpulan penelitian ini sebagai berikut yaitu menurut ajaran agama Hindu, Pajak dipungut oleh negara melalui fiskus (pemungut pajak) dengan besaran $8 \%$ sampai dengan 25\% berupa PBB, PPn, PPh, dan Bea Meterai. 
Pajak dalam ajaran Hindu merupakan sebuah kegiatan yadnya, yaitu kegiatan tulus ikhlas yang ditujukan sebagai bentuk penghormatan dan pengabdian warga masyarakat terhadap negaranya. Beberapa kitab seperti Arthasastra maupun Manawa Dharmasastra secara jelas menyatakan bahwa pajak memang diperkenankan dalam Hindu, artinya pajak merupakan pendapatan yang sah bagi negara dan pendapatan tersebut disalurkan kembali kepada masyarakat dalam bentuk pembangunan dan kesejahteraan seluruh rakyat. Kesadaran dan pengetahuan umat Hindu dalam membayar pajak sudah tergolong baik, sehingga perlu dipertahankan atau bahkan ditingkatkan sehingga kesadaran umat meningkat melalui sosialisasi dan sangsi bagi mereka yang masih menunda atau tidak membayar pajak. Umat Hindu di Kota Mataram secara umum telah menyadari pentingnya membayar pajak dan manfaat pajak yang dibayarkan bagi masyarakat yang disebabkan pengetahuan tentang pajak telah dipahami dimana warga masyarakat sudah mampu menunjukkan sumber-sumber pajak baik kitab Sruti dan Smerti.

Berdasarkan hasil dan kesimpulan yang ada, maka dapat direkomendasikan saran-saran sebagai berikut yaitu: bagi Umat Hindu dianjurkan agar meningkatkan kesadaran membayar pajak dan mempraktekan serta memberi contoh kepada sesama untuk menunbuhkan kesadaran bahwa pajak merupakan kewajiban bagi setiap warga negara, agar fasilitas yang diberikan oleh negara kepada masyarakat tetap terjaga bahkan meningkat. Selain itu, perlu meningkatkan kesadaran umat Hindu untuk membaca kitab Hindu dalam pengambilan keputusan dalam kegiatan seharihari, agar keputusan yang diambil tidak bertentangan dengan agama, terutama pemahaman terkait pajak dan bagi peneliti selanjutnya dapat mengembangkan model perpajakan dalam ajaran Hindu. 


\section{DAFTAR PUSTAKA}

Astana, Made, dan Anomdiputro. 2003. Arthasastra. Surabaya: Paramitha.

Dhavaleshwar, Chidanand U., Jyoti P. Vijapure, dan Ravikanth B. Lamani. 2013. Kautilya's View on Management, Tactful Management Research Journal, vol. 1 , issue. 11 , pp. 1-4.

Jotopurnomo, C. Dan Mangoting, Y. 2013. Pengaruh Kesadaran Wajib Pajak, Kualitas Pelayanan Fiskus, Sanksi Perpajakan, Lingkungan Wajib Pajak Berada terhadap Kepatuhan Wajib Pajak Orang Pribadi di Surabaya, Tax \& Accounting Review, Vol.1, No.1, pp. 49-54.

Mardiasmo. 2018. Perpajakan (Edisi Terbaru 2018). Yogyakarta: CV. Andi Offset.

Miles, Matthew B., dan A. Michael Huberman. 2009. Analisis Data Kualitatif: Buku Sumber Tentang Metode-Metode Baru. Jakarta: Penerbit Universitas Indonesia (UI Press).

Misman, Sofyeti. 2016. Pengaruh Penerapan Sistem Self Assessment Terhadap optimalisasi penerimaan PPH pasal 25 Wajib Pajak Badan pada KPP Pratama Manado, Jurnal Berkala Ilmiah Efisiensi, Vol.16 No.4, pp. 1074-1086.

Muniapan, Balakhrisnan. 2008. Kautilya's Arthashastra and Perspectives on Organizational Management, Asian Social Science, Vol. 4, no. 1, pp. 3034.

Nugeraha, A., Mandra, IG, dan Putra, INNA. Analisis Perbandingan Kinerja Keuangan Sebelum Dan Sesudah Diberlakukannya Tax Amnesty Periode Pertama Pada Perusahaan Sub Sektor Property Dan Real Estate Yang Terdaftar Di BEI, Distribusi, Vol.4, No.1, pp. 1-20.

Pudja, I Gde dan Tjokorda Rai Sudhartha. 1993. Manawa Dharma Castra (Manu Dharmacastra) atau Weda Smrti: Compendium Hukum Hindu, CV. Nitra Kencana Buana. Jakarta.

Putra, INNA. 2015. Riba dan Pembiayaan Dalam Konsep Hindu. Jurnal Keuangan dan Perbankan, Vol.19 No.3, pp. 488-496. 
Rohman, Saifur. 2013. Hermeneutik, Panduan ke Arah Desain Penelitian dan Analisis, Graha IImu. Jakarta.

Sharma, Sanjeev Kumar. 2005. Indian Idea of Good Governance Revisiting Kautilya 's Arthashastra, Dynamics of Administration, Vol. XVII, No. 12, pp.8-19.

Shyam, Manjula dan Shyam Sunder. 2008. Accounting and Governance in Kautilya's Arthasastra, Twelfth World Congress of Accounting Historians at Istanbul, Turkey, www.som.yale.edu/faculty/sunder/research/html.

Sihag, Balbir S. 2009. Kautilya on Law, Economics and Ethics, Humanomics Vol. 25 No. 1, pp. 75-94.

Yin, Robert K. 2009. Studi Kasus Desain dan Metode. Jakarta: Rajawali Pers. 